\title{
INISIASI EKOTEOLOGI BERWAWASAN GENDER DALAM AL-QURAN
}

\author{
Nur Arfiyah Febriani \\ Universitas Islam Negeri (UIN) Syarif Hidayatullah Jakarta \\ royyana12@yahoo.com
}

\section{ABSTRAK}

Ekoteologi adalah bentuk teologi konstruktif yang membahas interrelasi antara agama dan alam yang melibatkan hubungan antara pandangan dunia keagamaan manusia dan degradasi lingkungan. Krisis spiritual manusia modern mengakibatkan pola interaksi yang tidak harmonis manusia dengan lingkungan dan penggunaan sumber daya alam yang tidak bertanggungjawab. Di sisi lain, permasalahan gender stereotipe menyisakan permasalahan lain antara laki-laki dan perempuan yang saling berdebat terhadap faktor penyebab kerusakan lingkungan. Tulisan ini bertujuan untuk membuat gagasan tentang bagaimana pandangan al-Quran tentang penyelesaian masalah lingkungan yang dimulai dari membangun kesadaran teologis manusia dan relasi harmonis bagi laki-laki dan perempuan dengan lingkungan. Menggunakan metode tafsir maudu'i menurut al-Farmawi, artikel ini menemukan bahwa hubungan sistemik antara Tuhan, alam dan manusia yang keseluruhannya meniscayakan hubungan yang harmonis berdasarkan kesadaran teologis. Allah menyerahkan tugas khalifah/vice of God sebagai wakil Tuhan kepada manusia. Untuk menjamin keberlangsungan dan kebutuhan hidup manusia, Allah memperbolehkan manusia menggunakan sumber daya alam/user sekaligus sebagai pelindung/protector dan pelestari/conservator bagi lingkungan. Artinya, manusia baik laki-laki dan perempuan boleh menggunakan sumber daya alam sekaligus bertanggunngjawab sebagai konservatornya. Peran laki-laki dan perempuan digambarkan Al-Qur'an bersifat komplementer dan kooperatif. Alquran menyanggah stereotipe karakter bagi keduanya berdasarkan jenis kelamin.

Kata kunci: Ekoteologi, ekofeminisme, konservasi lingkungan, alQuran dan hadis. 
Inisiasi Ekoteologi Berwawasan Gender ...

\section{ABSTRACT}

Eco-theology is a constructive form of theology that discusses the interrelation between religion and nature. It involves the relationship between the religious view and environmental damage. The spiritual crisis of modern humans makes unharmonious interactions between humans and the environment. The stereotype gender issue leaves crucial issues between men and women about the environmental damage causes. This paper reveals how the Qur'an gives the solution to environmental problems. It begins with building a human theological awareness and a harmonious relationship between men and women on the environment. This study uses maudu'i tafsir method based on alFarmawi. The result finds that there is the systemic relationship between God, nature, and humans as a whole necessitate. It became a harmonious relationship based on theological consciousness. Human as a caliph in the world. God allows humans to use natural resources to consume and they must protect the environment. Both men and women can use natural resources as well as responsible. The role of men and women depicted by the Qur'an is complementary and cooperative. The Qur'an refutes the stereotype of characters for both by sex.

Keyword: Ecotheology, Ecofeminism, Environment Concervation, Quran and Hadis.

\section{A. Pendahuluan}

Ilmu kalam atau teologi adalah ilmu yang berbicara tentang prinsip-prinsip agama (Ușul al-Din) yang berkenaan dengan sistem kepercayaan agama (iman), yang tujuannya adalah untuk mempertahankan keyakinan agama (iman) dengan argumen-argumen yang bisa diterima akal (rasional) bagi manusia (Mulyadhi, 2006: 131-132).Sebagai ilmu yang paling fundamental dalam tradisi Islam, teologi Islam yang ada sudah kurang memadai. Oleh karena itu, harus dilakukan rekonstruksi teologis sesuai dengan perspektif modernitas. Dalam kepentingan ini, ia mengajukan ide baru yaitu neo kalam yang disebut juga sebagai teologi kontemporer (Syaukani, 1998: 74), karena teologi Islam bukan saja berisi tentang ideologi doktrinal sebagaimana yang dijabarkan dalam teologi Islam klasik maupun modern. Ajaran pokok dalam teologi Islam klasik baik yang dikembangkan oleh teolog islam rasional maupun teolog Islam tradisional berkisar tentang Tauhid, kekuasaan Tuhan dan kebebasan manusia, peran akal dan wahyu, ruh, alam semesta, pelaku dosa besar dan sebagainya (Harun Nasution, 1986). Dalam Teologi Islam kontemporer juga berisi tentang revolusi 
ideologis guna menyikapi permasalahan dan tantangan modernitas. Teologi Islam kontemporer adalah merupakan teologi kreatif produktif dari dinamika teologis Islam (Mujiono, 2001: 34-36).

Dari perkembangan pemikiran tersebut, muncul kajian baru dalam ilmu kalam yang berhubungan dengan ekologi, yang disebut dengan teologi lingkungan Islam/ekoteologi. Ilmu ini didefinisikan dengan konsep keyakinan agama yang berkaitan dengan persoalan dan permasalahan lingkungan yang didasarkan pada ajaran agama Islam. Menurut Mujiono, rumusan teologi lingkungan dapat digunakan sebagai panduan teologis berwawasan lingkungan dalam pengelolaan sumberdaya alam dan lingkungan. Konsep teologi lingkungan yang ditawarkan adalah konsep ekoreligi Islam yang dapat menjadi salah satu satu tawaran antisipatif ekologis spiritual religius Islami (Mujiono, 2001, ix-xii).

Mujiono membuat rumusan prinsip dasar teologi lingkungan Islam atau the principle of Islamic echoteology dengan pokok-pokok teologis antara lain:

1. Hakikat orang beriman adalah, orang yang percaya bahwa Allah adalah pencipta pertama lingkungan dan pemilik lingkungan tanpa bermilik serta pemelihara terbaik lingkungan. Mereka juga percaya kepada metasosialsystem, bahwa manusia adalah makhluk paling bertanggung jawab dalam pelestarian lingkungan. Baik tanggung jawab secara ekologis maupun secara spiritual religious. Sebab, niche ekologis manusia adalah mandataris ilahi, sebagai pelestari lingkungan aktual.

2. Rukun iman pembangunan ada tiga: percaya bahwa pembangunan merupakan keniscayaan dan manusia adalah makhluk pembangunan, serta pembangunan hakiki adalah pembangunan berkesinambungan dan berkelanjutan.

3. Peduli lingkungan sebagian dari iman, maka tidak sempurna iman seseorang jika tidak peduli lingkungan. Oleh sebab itu, jangan sekali-kali mengaku dirinya insan beriman jika tidak peduli lingkungan.

4. Merusak lingkungan adalah kufur ekologis, sebab merusak lingkungan adalah perilaku syaitaniac. Oleh karena itu merusak lingkungan termasuk salah satu perilaku dosa besar, maka jauhilah. 
Mujiono lebih lanjut mengatakan bahwa energi itu terbatas, oleh sebab itu hemat energi adalah sebagian dari iman. Janganlah mengaku dirinya sebagai insan beriman jika tidak hemat energi. Sedangkan boros energi adalah sebagian dari kufur ekologis. Maka hindarilah pemborosan energi (Mujiono, 2001, x-xii).

Dengan demikian, tergambar hubungan harmonis antara Tuhan, alam dan manusia dari konsep ekoteologi Islam yang bersifat sistemik. Demikian dalam ajaran agama Kristen, hubungan antara Tuhan, alam dan manusia mengacu pada hubungan struktural, yaitu Tuhan sebagai pencipta manusia dan alam raya dan Tuhan sebagai pemilik manusia serta alam raya serta hubungan fungsional Tuhan sebagai pemelihara manusia dan alam raya (William Greenway, 2010: 82).

Dengan tugas manusia sebagai khalifah/wakil Tuhan (Q.S. al-Baqarah [2]: 30 dan Q.S. Shad [38]: 26) yang juga dapat dipahami dalam arti manusia sebagai protector dan conservator alam raya (Febriani, 2014). Tulisan ini mencoba untuk mengembangkan wawasan gender dalam kajian ekoteologi yang tidak ada dalam pembahasan disertasi penulis.

\section{B. PEMBAHASAN}

Dalam perspektif al-Qur'an, etika teologi memiliki hubungan dengan etika alam yang dikenal dengan istilah ekoteologi. Esensi dari etika ekoteologi ini adalah, etika manusia dalam upaya harmonisasi hubungannya kepada Sang Pencipta. Dari harmonisasi hubungan kepada sang Pencipta, akan terjalin pula hubungan yang harmonis antara individu manusia dengan sesama manusia, dan dengan sesama makhluk lainnya di alam raya. Dari kesadaran teologis ini, menyadarkan manusia akan eksistensi Tuhan sebagai Yang Maha Mencipta, menyadari bahwa alam semesta juga sesama makhluk ciptaan-Nya yang harus dihargai eksistensinya.

Dalam banyak ayat dalam al-Qur'an, Allah sering menyandingkan antara pernyataan diri-Nya sebagai Sang Pencita kepada manusia, dan perintah bagi manusia untuk memperhatikan dirinya sendiri dan mempelajari alam raya agar manusia dapat menangkap isyarat ilmiah sebagai tanda-tanda keberadaan Allah dan kekuasaan Allah dalam menciptakan manusia dan alam raya, agar menambah keimanannya sebagaimana isyarat Allah dalam Q.S. al-'Ankabūt [29]: 61:

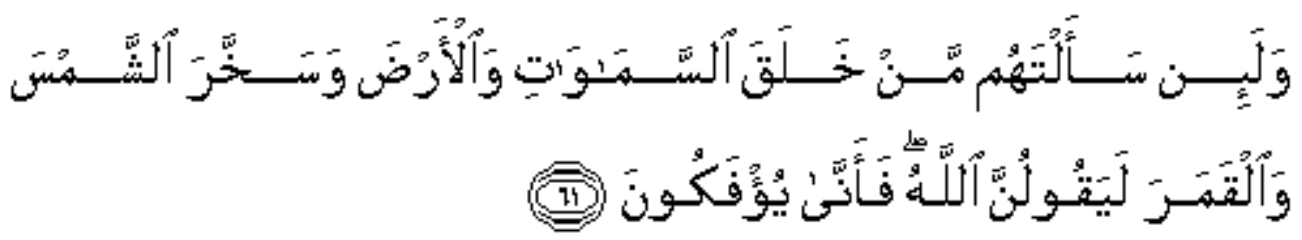


Artinya: dan Sesungguhnya jika kamu tanyakan kepada mereka: "Siapakah yang menjadikan langit dan bumi dan menundukkan matahari dan bulan?" tentu mereka akan menjawab: "Allah", Maka betapakah mereka (dapat) dipalingkan (dari jalan yang benar).

Ayat di atas, menjelaskan bahwa Allah adalah satu-satunya pencipta langit dan bumi dan yang menundukkan matahari dan bulan, tidak ada keraguan di dalamnya. Dengan konsep iman dalam teologi Islam ini, manusia akan menjadikan Allah sebagai satu-satunya Tuhan yang disembah. Keimanan manusia ini, mendeskripsikan jiwa manusia yang murni (HAMKA, juz. XXIXXII, 23-24).

Namun ironisnya, interrelasi antara Allah, manusia dan alam raya yang sesungguhnya digambarkan harmonis, kurang tersentuh oleh perhatian manusia ketika membaca teks ajaran yang terkandung di dalamnya. Akibatnya, aktualisasi ajaran normatif mengenai hubungan harmonis inipun, justru menjadi tidak harmonis. Ini terbukti dengan semakin maraknya penelitian tentang krisis spiritual, krisis akhlak dan krisis lingkungan, yang keseluruhannya memiliki keterkaitan.

Umat Islam khususnya, mayoritas sebatas menjalani ajaran agama yang bersifat ritual, padahal jika dipahami lebih jauh ajaran agama yang tertuang dalam Alquran dan hadis, esensi dari ajaran itu sendiri adalah pedoman untuk menjalani hidup yang lebih baik. Jika saja dipahami semangat Alquran yang kerap memerintahkan manusia untuk lebih mendalami tentang harmonisasi hubungan antara Tuhan, alam dan manusia, tentu tidak akan ada permasalahan krisis spiritual, sosial dan lingkungan, yang menjadi penyakit berjamaah manusia modern saat ini.

Oleh sebab itu, sebagai basis yang menjadi sumber permasalahan, yaitu hubungan manusia dengan tuhan yang kurang harmonis yang berimbas pada kurang harmonisnya hubungan manusia kepada sesama manusia dan alam, penting sekali untuk mengupas etika teologi ini diawal kajian etika lingkungan yang dideskripsikan Alquran.

Sebagaimana diungkapkan sebelumnya, dalam perkembangan konsep teologi yang berhubungan dengan krisis lingkungan, lahir disiplin ekoteologi. Meskipun pada dasarnya teologi merupakan disiplin yang membahas tentang keimanan, yang tujuannya adalah untuk mempertahankan keyakinan agama (iman) dengan argumen-argumen yang bisa diterima akal manusia (rasional), namun ia juga terikat oleh konteks lingkungan (kosmos) dan manusia. Oleh sebab itu, bahasan teologi di sini dibatasi pada pengertian di atas, dan tidak diletakkan dalam diskursus ilmu kalam (Febriani, 2014: 44-47). 
Menurut Mudhofir, dalam konteks konservasi lingkungan, ekoteologi dibutuhkan untuk menopang argumen-argumen etis, teologis, dan filosofis sehingga diskursus mengenai konservasi lingkungan memiliki kaitan rapat dengan Allah (Mudhofir, 95).

Ekoteologi adalah bentuk teologi konstruktif yang membahas interrelasi antara agama dan alam, terutama dalam menatap masalah-masalah lingkungan. Secara umum, ekoteologi berangkat dari suatu premis bahwa ia ada karena adanya hubungan antara pandangan dunia keagamaan manusia dan degradasi lingkungan.

Ekoteologi menjadi diskursus yang menarik karena ekoteologi mengakomodir dan menyatukan seluruh umat manusia ke dalam suatu keluarga biotik besar yang hidup dalam satu pusaka bersama (bumi). Ekoteologi adalah suatu hal yang menjanjikan dan menjadi semacam spirit keagamaan di masa depan (Albert Gore, Jr, 1992: 269). Dalam ekoteologi tercakup dimensi spiritual, keimanan, pandangan-dunia (world view), etika, moralitas, dan agama, sehingga gabungan dari semua itu dapat menentukan dasar pemahaman manusia yang lebih komprehensif tentang bagaimana ia harus menempatkan diri di alam semesta (Harold W. Wood, Jr, 1985).

Selanjutnya, dalam kacamata ekoteologi Yūsuf al-Qaraḍ̄̄ỉ menyatakan, usaha memelihara lingkungan dapat menumbuhkan perasaan insyaf di antara orang-orang yang selalu bersujud dan mensucikan Allah dengan perasaan cinta dan sayang. Karena, seluruh ciptaan Allah juga beribadah dan bersujud kepada Allah SWT dengan cara mereka masing-masing, yang hanya Allah yang mengetahuinya (al-Qaraḍāwi, 36). Hal ini sebagaimana isyarat Allah dalam firman-Nya dalam Q.S. al-Isrā' [17]: 44 yang berbunyi:

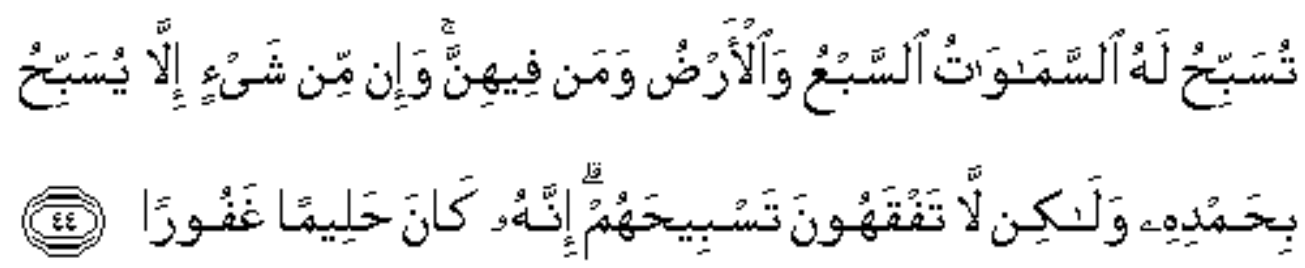

Artinya: langit yang tujuh, bumi dan semua yang ada di dalamnya bertasbih kepada Allah. dan tak ada suatupun melainkan bertasbih dengan memuji-Nya, tetapi kamu sekalian tidak mengerti tasbih mereka. Sesungguhnya Dia adalah Maha Penyantun lagi Maha Pengampun.

Para mufasir seperti Ibnu Kathir (Juz. V, 72-74), Ṭanțawi Jauhari (Juz. V, 55), al-Majlisi (Juz. 57, 164-167), Fakhr al-Rāzi (Juz. X, 220-221), Sa id Hawwa (Juz. XI, 3079-3080), dan al-Biqā́r (Juz IV, 385-386), serempak menafsirkan kata tasbih dalam ayat ini dalam arti: tasbih bagi manusia adalah dengan lisannya, sedang 
bertasbih bagi makhluk Allah selain manusia yang ada di alam raya ini, yaitu bertasbih sesuai dengan keadaan masing-masing suatu makhluk, yang tidak dapat dipahami manusia karena keterbatasan manusia itu sendiri.

Al-Nursi (al-Nursi, 1999 H/1420 M: 422) menyatakan bahwa keberadaan suatu makhluk di alam raya ini, menunjukkan kehadiran Allah sebagai Tuhan yang Maha Mencipta, yang menciptakan segala sesuatu dengan sangat teratur, memiliki karakter sesuai dengan fungsinya dan kondisi yang sangat tepat. Keseluruhan makhluk di alam raya menuju kepada Allah swt, bertasbih dan beribadah kepada Allah dengan cara senantiasa patuh kepada ketetapan Allah

Selain itu dalam ayat lain dikatakan bahwa "sujud" segala sesuatu yang ada dilangit dan di bumi kepada Allah (Q.S. al-Rahmān [55]: 6). Untuk kata sujud bagi alam raya, Hamka memahaminya dengan tunduknya semua ciptaan Allah untuk menjalani fungsi masing-masing sesuai dengan ketetapan-Nya, penundukkan ini agar manusia dapat menjalani kehidupan di dunia dengan mengambil manfaatnya secara bijak (HAMKA, juz XXVII-XXVIII, 183). Bagi umat yang beriman berbagai macam makhluk yang berada di langit dan dibumi adalah tanda-tanda kekuasaan Allah (Q.S. Al-Jāthiyah [45]: 3), dan mempelajarinya akan sangat banyak memberikan manfa'at dan akan menambah keimanan orang yang beriman (Q.S. Al-Dhāriyāt [51]: 55).

Ada berbagai macam hikmah di balik penciptaan alam raya, di antaranya yaitu Allah ingin menunjukkan kepada manusia akan eksistensi-Nya dibalik penciptaan berbagai makhluk yang ada di alam raya. Tunduknya alam pada ketetapan Allah dengan konsisten menjalankan fungsinya, memberi tanpa pretensi meminta kembali, berbagai keindahan yang terkandung di dalamnya, keteraturan gerak dan posisi, serta ilmu pengetahuan yang terkandung di dalamnya, ternyata untuk suatu manfaat yang diperuntukkan untuk menunjang dan menjadi sumber kehidupan manusia, yang dipercaya menjadi wakil Allah untuk menjaga eksistensi berbagai makhluk ciptaan-Nya di dunia. Namun yang terpenting adalah dengan pengetahuan yang terkuak tersebut akan menambah keimanan manusia kepada Allah SWT. Isyarat ini dapat dilihat pada beberapa ayat seperti: Q.S. al-Baqarah [2]: 117, Āli 'Imrān [3]: 47 dan 59, al-An'ām [6]: 73, al-Nahl [16]: 40.

Ketundukan dan kepasrahan alam raya dengan ketetapan Allah menjadikan alam raya di dalam al-Qur'an dikatakan sebagai "muslim" (Fazlul

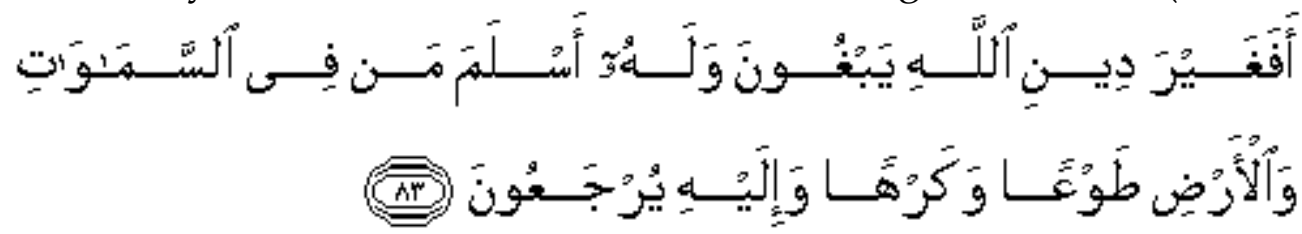


Rahman, 1999: 65). Hal ini sebagaimana isyarat Allah dalam al-Qur'an surat Āli 'Imrān [3]: 83 yang berbunyi:

Artinya: Maka Apakah mereka mencari agama yang lain dari agama Allah, Padahal kepada-Nya-lah menyerahkan diri segala apa yang di langit dan di bumi, baik dengan suka maupun terpaksa dan hanya kepada Allahlah mereka dikembalikan.

Ayat di atas menjelaskan, ketundukan segala macam makhluk yang Allah ciptakan, adalah bukti mereka pasrah kepada Yang Menciptakan. Alam beserta isinya beribadah dengan bertasbih kepada Allah (Q.S. al-Hadid [57]: 1), mereka tetap pada ketentuan Allah untuk konsisten menjalani fungsinya, dan alam memberikan manfaat tanpa pamrih (Q.S. al-Mu'minūn [40]: 68). Hal ini berbeda dengan manusia, padahal ajaran ikhlas/melakukan sesuatu tanpa pretensi apapun kecuali untuk Allah semata adalah sebagian ajaran yang Allah juga berikan kepada manusia. Sayangnya, manusia yang dikatakan memiliki berbagai macam kelebihan dibanding makhluk lain, justru sering melupakan Tuhannya dan membangkang dengan ketentuan Allah.

Murninya ketundukkan alam, tanpa pretensi apapun kecuali untuk ta'at pada ketetapan Allah, menunjukkan ibadah universal. Alam dalam hal ini, dapat dikatakan lebih berakhlak baik dibanding manusia yang senang membangkang dengan ketetapan Allah. Padahal, setiap bentuk ajaran berupa perintah dan larangan yang tedapat dalam Alquran dan hadis serta kemampuan think and feel bagi manusia, untuk semakin membuat manusia menyadari hikmah dibalik semua ketetapan Allah.

Dari sini dapat dipahami, ternyata di dalam Alquran bukan hanya manusia yang dikatakan makhluk spiritual yang memiliki potensi beribadah kepada Sang Pencipta, bahkan seluruh makhluk ciptaan-Nya di alam raya ini, beribadah tanpa pembelotan, pembangkangan, akan tetapi ikhlas tanpa pretensi apapun (Q.S. al-Nahl [16]: 49).

Berbeda dengan alam yang sepenuhnya tunduk dan pasrah pada kekuasaan Allah dan ketetapan-Nya, argumentasi yang mengajak kepada kesadaran teologis yang banyak didengungkan Alquran untuk manusia, ternyata tidak selalu mengingatkan kelalaiannya dalam mentadaburi firman Allah untuk meningkatkan intensitas hubungan harmonis dengan-Nya.

Padahal Alquran menunjukkan kebesaran Allah dalam diri manusia sendiri dan segala makhluk ciptaan-Nya yang terhampar di alam raya. Alquran mengisyaratkan alam raya sebagai sarana manusia menyadari akan keesaan Allah yang Maha Pencipta, agar manusia juga mendapat balasan dari apa-apa yang ia perbuat. 
Artinya, alam dalam perspektif Alquran juga dapat dipahami sebagai sarana manusia untuk meningkatkan kesadaran teologis manusia. Ini menurut Nasr karena Alquran dan alam semesta (cosmos) memiliki kesamaan wujud. Alquran adalah wahyu yang diturunkan dengan berbagai simbol tulisan dan kata yang terhimpun (the recorded Quran), sedang alam adalah wahyu dalam bentuk kosmik (takwin). Alam adalah sebuah buku yang berisi "wahyu primordial". Dengan demikian dapat dipahami bahwa "Alquran dan alam" adalah "kitab suci" Tuhan (Noer, 1999: 64-66 dan Nasr, 2004: 199).

Kesadaran teologis juga ditekankan dalam Alquran, ketika Alquran menginspirasikan manusia agar tidak sombong dan senantiasa menyadari keterbatasannya, karena sehebat apapun manusia pasti akan mengalami kematian. Pada saat itulah, Allah menepati janji-janji-Nya dalam Alquran untuk memberikan ganjaran atas setiap amal ibadah yang ditanam manusia selama di dunia, yang akan menjadi teman yang menjadi saksinya kelak di akhirat (lihat: Q.S. al-Baqarah [2]: 82 dan Q.S. Âli ‘Imrān [3]: 57). Allah juga berfirman:

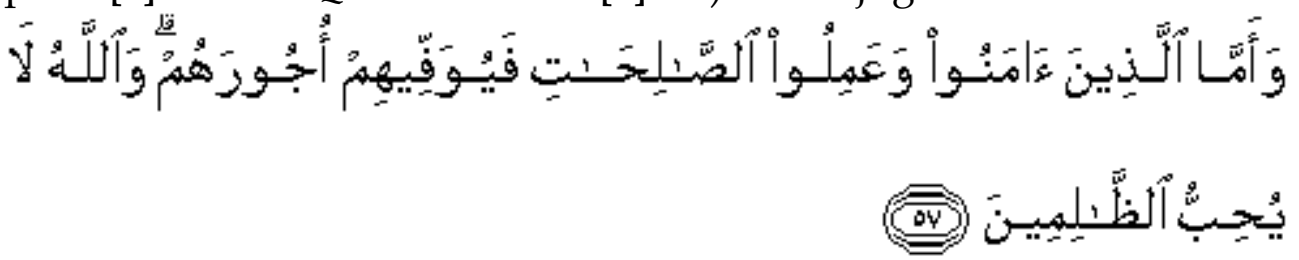

Artinya: Adapun orang-orang yang beriman dan mengerjakan amalan-amalan yang saleh, Maka Allah akan memberikan kepada mereka dengan sempurna pahala amalan-amalan mereka; dan Allah tidak menyukai orang-orang yang zalim.

Menurut Quraish Shihab, ayat di atas menjelaskan tentang argumentasi keniscayaan hari kiamat. Pertama, Allah menciptakan alam raya ini dengan haq, dan karena dalam kehidupan ini manusia akan punah atau belum mencapai tingkat kesempurnaan dengan haq yang dikehendaki Allah bahkan didambakan oleh seluruh manusia, maka tentu saja masih ada alam lain yang tercapai disana haq sempurna yang didambakan itu.

Kedua, argumentasi perlunya memberi balasan terhadap kebaikan dan kejahatan yang dilakukan oleh manusia. Karena jika dalam kehidupan dunia ini masih banyak manusia yang tidak menemukan balasan dan ganjaran perbuatannya, bahkan ada yang memperoleh kenikmatan duniawi akibat kejahatannya, demikian pula sebaliknya. Karena itu, diperlukan adanya waktu tertentu-selain dalam kehidupan ini-sehingga masing-masing memperoleh balasan yang sesuai dan tepat (Shihab, 2005: Vol. 13, 52).

Namun demikian Alquran mengingatkan manusia, baik laki-laki dan perempuan akan kehidupan yang justru penuh dengan kenikmatan kelak di 
akhirat jika manusia senantiasa menjalankan ajaran yang terkandung di dalamnya selama hidup di dunia. Inipun masih dengan catatan, bahwa sebaik apapun perbuatan manusia, kelak manusia akan masuk ke dalam surga bukan hanya karena amal perbuatannya, akan tetapi dengan rahmat dari Allah swt. Ini adalah agar manusia tidak sombong dan menyadari betapa besar rahmat Allah SWT yang telah dan akan dilimpahkan padanya kelak di akhirat. Hal ini sesuai dengan hadis riwayat Muslim no. 5042 yang berbunyi:

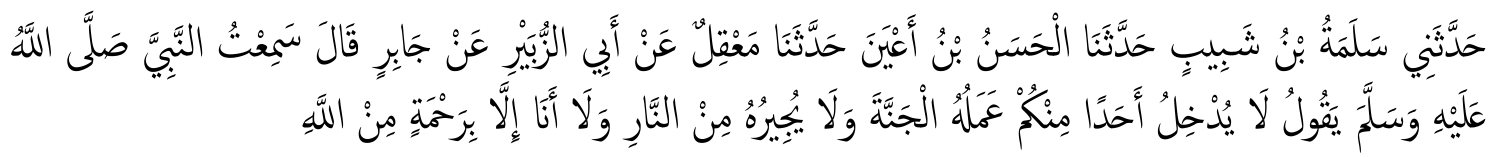

Berdasar pembahasan di atas dapat dipahami bahwa, kesadaran teologis tentang ketauhidan, akan membawa manusia senantiasa bertaqarrub (mendekatkan diri) kepada-Nya. Manusia akan menyadari keterbatasannya, dan menyadari bahwa kehidupan di dunia hanya bersifat sementara (fana). Ada tujuan tertinggi dari proses dinamika kehidupan dunia, yaitu kehidupan yang kekal di akhirat kelak. Kesadaran teologis ini akan membawa dampak positif terhadap kesadaran ekoteologi.

Selain itu menurut Maria Jaoudi, ketauhidan adalah kepercayaan pada kesatuan dalam kehidupan. Maria menggunkan istilah God-centered-ecology yang dimulai dengan dan percaya kepada Tuhan. Tanpa ini dalam kehidupan seseorang menurut tradisi sufi dan saintis Kristen, akan membuat seseorang kehilangan esensinya dengan sumber hidup (Tuhan) dan makhluk ciptaanNya. Gejala ini dapat disaksikan manakala manusia yang sangat konsen terhadap isu seputar lingkungan, tapi menjadi lemah dan lelah secara emosional dan spiritual, saat mereka tidak memiliki keteguhan dalam dirinya, yaitu ketauhidan itu sendiri (Maria Jaoudi, 1993: 74).

Artinya, relasi harmonis antara manusia dengan Allah sebagai pencipta alam raya ini, akan membuat manusia menyadari hakikat alam raya dan menghargai eksistensi alam raya sebagai sesama makhluk ciptaan Allah. Hal ini akan membawa efek positif berupa rekonstruksi paradigma manusia terhadap alam yang selama ini cenderung antroposentris kepada teori yang penulis sebut dengan ekohumanis teosentris yang penulis usung dalam disertasi penulis, untuk "membedakan" paradigma etika lingkungan dalam perspektif Islam, yang berlandaskan tauhid. Hal ini tentu berbeda dengan etika lingkungan dalam perspektif agama lain, yang jelas berbeda dari segi keimanan dan tauhid itu sendiri. Etika lingkungan yang dibaca dari susut pandang agama lain, biasanya 
menggunakan istilah: deep ecology (Naess dan Berry, 1995), spiritual ecology (Merchant, 2002), ecological spirituality (Gullick 1991), greening religion (Warner), green spirituality (Rosmani, 2004).

Paradigma ini akan memberikan kesadaran kepada manusia akan pentingnya merefleksikan hubungan yang harmonis dengan dirinya sendiri, kepada sesama manusia,kepada segenap makhluk Allah di alam raya ini dan kepada Allah SWT. Terdapat hubungan sistemik antara Tuhan sebagai Sang Pencipta, manusia sebagai wakilNya dan alam sebagai makhluk ciptaan Tuhan yang juga memiliki potensi beribadah dan memiliki fungsi masing-masing di alam raya, yang keseluruhannya digambarkan memiliki relasi yang harmonis.

Dalam penjelasan ayat lain, terkait hubungan antara kesadaran teologis manusia dengan pola interaksi manusia dengan lingkungan, semangat egaliter yang diusung Alquran membawa umatnya untuk mengoptimalkan potensi akal (intelektual) dan hati (emosional) yang dianugerahkan Allah kepadanya. Alquran tidak memandang perbedaan laki-laki dan perempuan sebagai dua jenis manusia yang memiliki potensi akal dan hati yang lebih antara yang satu dengan yang lain. Dalam disertasi penulis diungkapkan pada bahwa di dalam Alquran terdapat isyarat keseimbangan potensi tersebut di dalam diri manusia. Ini yang menjadikan manusia memiliki potensi dan kesempatan yang sama dalam menunjang eksistensi dan meraih prestasi dalam kehidupan mereka (Febriani, 2014: 158-162).

Hal ini bertolak belakang dengan pendapat ahli biologi seperti Unger. Menurutnya, terdapat distingsi akibat perbedaan faktor biologis bagi laki-laki dan perempuan terhadap potensi keduanya. Perempuan dinilai lebih emosional sedang laki-laki lebih potensial dalam intelektualnya. Padahal sterotip bagi perempuan ini sebagaimana dikutip dari pendapat Mary Wollstonecraft, disebabkan perempuan terlanjur dididik menjadi makhluk emosi daripada rasio (Wollstonecraft, 1995).

Ironisnya, ketimpangan pembagian potensi yang kurang menguntungkan bagi perempuan yang telah membudaya seperti versi Unger ini, mengakibatkan perempuan dinilai hanya layak berperan dalam ruang domestik. Hal ini masih ditambah dengan pemahaman yang kurang obyektif kebanyakan masyarakat tentang ayat-ayat Alquran dan hadis Nabi yang masih memahaminya secara tekstual.

Sebaliknya, dalam isu kerusakan ekologi dan hubungannya dengan ketimpangan genderyang dialami perempuan dalam 4 (empat) dekade ini, menyebabkan potensi intelektual laki-laki yang membuat mereka dinilai 
Inisiasi Ekoteologi Berwawasan Gender ...

bersikap ambisius dan otoriter, sering dikatakan sebagai biang keladi rusaknya tatanan alami alam (Cuamo, 1998: 23). Perempuanpun merasa lebih potensial dalam menyembuhkan gejala penyakit yang dialami bumi. (Bolen, 2004).

Dari berbagai perbenturan pemikiran di atas, bermunculan diskursus seputar ekologi dan kaitannya dengan cabang ilmu yang lain, para ahli berusaha mencari solusi kerusakan alam berdasarkan keahlian masing-masing. Namun solusi tersebut masih tersaji secara terpisah, oleh sebab itu buku ini mencoba menyusun puzel yang masih terpisah tersebut untuk dapat disajikan dalam kesatuan yang utuh.

Menariknya, aktifis gender memunculkan aliran baru yang mereka beri nama ekofeminis. Aliran ini lahir dari keprihatinan mereka terhadap isu kerusakan lingkungan yang mereka anggap memiliki korelasi dengan perlakuan diskriminatif yang dialami kaum perempuan (Canas, 1996: 27). Aliran ekofeminis ini terbagi menjadi tiga kelompok, yaitu: ekofeminis radikal, liberal dan sosial.

Ciri has dari gerakan ekofeminis radikal adalah mengkritik dan menolak segala bentuk dominasi laki-laki atas perempuan dalam berbagai bidang. Bagi ekofeminis radikal, budaya patriarki harus dihapuskan karena budaya inilah yang menjadi penyebab utama keterbatasan bagi perempuan, meskipun ada upaya pemerintah dalam membuat kebijakan pemberdayaan perempuan, sebagai upaya improvisasi posisi perempuan dalam berbagai lini dalam kehidupannya (Betty Plewes dan Ricky Stuart, 1991: 107-132).

Starhawk seorang tokoh ekofeminis radikal mengungkapkan, aliansi perempuan dengan alam dikarenakan perempuan memiliki kapabilitas reproduksi, kualitas emosi, dan aktifitas yang berhubungan dengan pemeliharaan, predikat ini nyaris mengisolasi perempuan untuk hanya beraktifitas pada bidang yang berkaitan dengan tiga hal tersebut (Starhawk, 1987: 1).

Tokoh lainnya seperti Ynestra King menganggap sterotip perempuan yang selalu dalam dominasi laki-laki, menyatakan adanya "dual subordinasi" antara perempuan dan alam sebagai korban dari budaya patriarki. Laki-laki sering menjadikan alibi reproduksi perempuan menjadi keterbatasannya dalam mengembangkan potensi diri, oleh sebab itu laki-laki juga merendahkan eksistensi bumi dan senang membahayakan kelangsungan hidup manusia dan berbagai spesies di muka bumi dengan sikap dominasinya (Hessing, 1993: 3). Di sisi lain, ekofeminis liberal mencoba membangkitkan semangat kaum perempuan untuk meningkatkan kualitasnya melalui pendidikan agar dapat 
menunjang eksistensi sosialnya, yang pada akhirnya akan membawa kesamaan akses bagi laki-laki dan perempuan dalam struktur ekonomi dan politik. Hal ini tentu saja dengan tetap responsibel terhadap tugas kerumahtanggaan, agar terpelihara antara keadilan sosial dan pribadi.

Sementara ekofeminis sosial yang diilhami oleh Marxisme dengan budaya kapitalisnya, menganggap subordinasi perempuan tidak hanya disebabkan devaluasi dari laki-laki, akan tetapi sebagai tujuan dari upaya pemeliharaan stabilitas, dan rendahnya upah bagi tenaga kerja perempuan sekaligus sebagai pemelihara rumah. Ekofeminis sosial menyadari, mayoritas inisiatif kebijakan politik untuk terus melanjutkan menyerahkan kepercayaan ini kepada perempuan sebagai sosok pribadi yang ramah agar sistem kapitalis dapat terus berjalan.

Oleh sebab itu ekofeminis sosial berkonsentrasi pada korelasi antar kemiskinan kaum perempuan dan peningkatan polarisasi global. Mereka menghubungkan antara ekspansi dan peningkatan mobilitas perusahaan multinasional dengan terkikisnya antara hak asasi manusia dan kualitas lingkungan (Hessing, 1993: 11; Bina, 1992).

Linda Vance (1997) dan Agarwal Bina (1992) menyatakan, kesatuan pemikiran para tokoh ekofeminis dari berbagai aliran tersebut terletak pada kesamaan pendapat bahwa dominasi budaya patriarki laki-laki atas perempuan yang pararel dengan dominasi patriarki laki-laki terhadap alam. Baik perempuan dan alam telah dikontrol dan dimanipulasi untuk memenuhi hasrat laki-laki. Menurut Ynestra King dan Carolyn Merchant (Chris J. Cuamo, 1998 dan Mary Daly (1978), argumen ini disebabkan karena anggapan bahwa perempuan secara ideologi dikonstruksikan lebih dekat dengan alam karena faktor biologis mereka (Carolyn Merchant, 1980: 144, dan Susan Griffin, 1978). Lebih ironis lagi, menurut Vandana Shiva kekerasan dan penganiayaan terhadap perempuan bukan hanya secara ideologi akan tetapi secara materi (Shiva, 1988: 39).

Bagi Merchant dalam investigasi akar dari dilema lingkungan saat ini, pandangan terdahulu mengenai identitas alam sebagai seorang ibu yang memelihara, menghubungankan sejarah perempuan dengan sejarah lingkungan dan perubahan ekologi, sains, teknologi dan ekonomi. Merchat menulis:

"Kita harus menguji kembali pembentukan cara pandang dunia dan sains, bahwa dengan rekonseptualisasi realita tentang dunia yang dinilai sebatas sebagai sebuah mesin lebih baik daripada cara pandang bahwa dunia adalah sebuah organisme yang hidup, sama dengan menyetujui dominasi antara alam dan wanita". 
Hal ini melukiskan betapa sulitnya mereformasi budaya patriarki, yang imbas negatifnya juga melingkupi budaya dominasi terhadap alam.

Dari seluruh perdebatan di atas, penulis menyimpulkan hubungan antara dominasi perempuan dan alam didasari dari ideologi, yang menjadi akar dari sebuah sistem, nilai dan kepercayaan, yang menempatkan perempuan dan makhluk selain manusia secara hirarki dibawah laki-laki. Ini mengundang lakilaki dan perempuan untuk merekonseptualisasikan diri mereka, dan hubungan mereka kepada sesama manusia dan kepada selain manusia (alam), dalam cara yang non-hirarki (Bina, 1992: 2; Shiva, 1996: 65-73).

Oleh sebab itu, sebagai akar dari permasalahan kesalahpahaman manusia terhadap teks keagamaan yang berimbas pada pola interaksi manusia terhadap sesamanya bahkan terhadap alam, perlu dilakukan rekonstruksi pemahaman seputar anggapan tersebut. Kedua sterotip bagi perempuan dan laki-laki di atas adalah tuduhan yang harus dibaca dan dianalisa dengan lebih cermat.

Dalam Alquran, banyak ayat yang memberikan motivasi kepada umat Islam baik laki-laki dan perempuan untuk hidup harmonis, sekaligus menjadi pribadi yang aktif dan progresif di antaranya pada Q.S. al-Zalzalah [99]: 7-8, alNisā' [4]: 124, al-An'ām [6]: 132, Yūnus [10]: 9, al-Fușṣilat [41]: 46, . Al-Kahf [18]: 1-2, Al-Aḥzāb [33]: 47, Al-Jāthiyah [45]: 15, Fāṭir [35]: 10, Q.S. Āli ‘Imrān [3]: 30, al-Zumar [39]: 70, al-Ṭūr [52]: 21, Ṭāhā [20]: 112, al-Anbiyā' [21]: 94, al-Isrā' [17]: 19,Q.S. al-Kahf [18]: 30, dan al-Mu' min [40]: 40. Keduanya dideskripsikan sebagai pribadi yang masing-masing memiliki kualitas/karakter feminin dan maskulin dalam dirinya. Dengan keseimbangan karakter dan berbagai potensi yang samasama dimiliki laki-laki dan perempuan, keduanya memiliki kesempatan yang sama untuk meraih prestasi, kesuksesan di dunia dan akhirat.

Alquran mencatat manusia diberi kebebasan menentukan karakter apa yang akan mempresentasikan dirinya. Karakter feminin dan maskulin memiliki sisi positif dan negatif.Sisi negatif inilah yang kemudian menjadi stereotipe bagi laki-laki dan perempuan.Manusia yang baik adalah, manusia yang mampu menyeimbangkan karakter feminin dan maskulin yang positif dalam dirinya sebagaimana yang dicontohkan Rasulullah. Klasifikasi karakter karakter feminin dan maskulin yang memiliki nilai positif dan negatif dalam perspektif Alquran, dapat diilustrasikan sebagai berikut: 


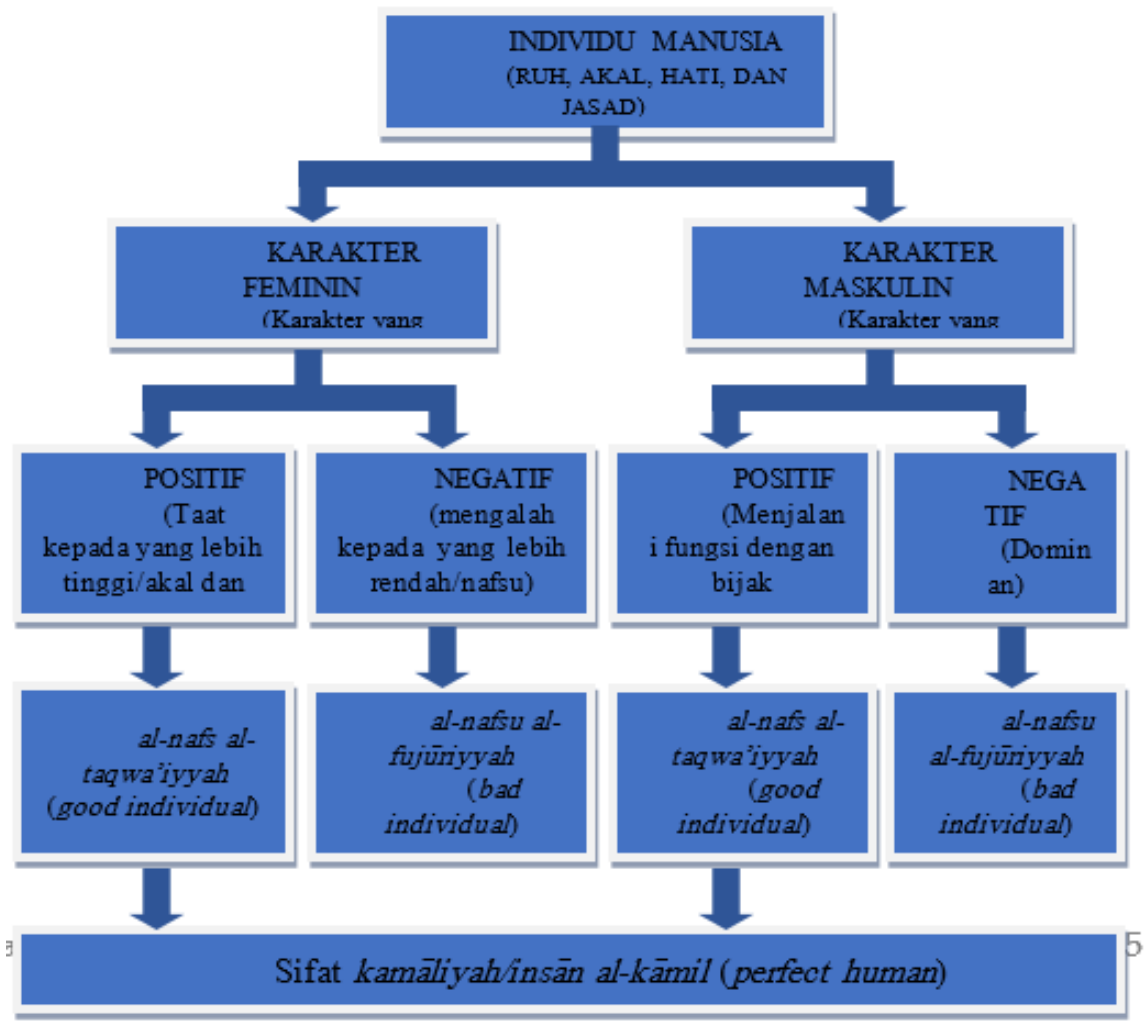

Gambar 1 Keseimbangan Karakter Feminin dan Maskulin dalam Diri Manusia

Dari gambar 1 dapat diketahui bahwa, masing-masing individu manusia memiliki keseimbangan karakter feminin dan maskulin dalam dirinya.Dengan memilih mengoptimalkan kedua karakter feminin dan maskulin yang positif dalam dirinya, manusia dapat belajar memiliki pribadi yang sempurna dan dapat diterima dengan baik dalam hubungan sosialnya.

Salah satu ayat yang sangat menarik untuk dapat merekonstruksi paradigma masyarakat di atas tentang sterotip bagi perempuan dan laki-laki adalah Q.S. Âli ‘Imrān [3]: 104 :

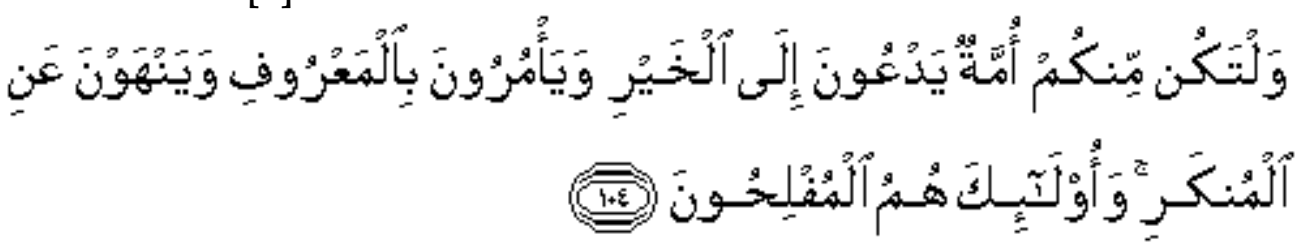

Artinya: dan hendaklah ada di antara kamu segolongan umat yang menyeru kepada kebajikan, menyuruh kepada yang ma'ruf dan mencegah dari yang munkar; merekalah orang-orang yang beruntung.

Dalam ayat ini, umat Islam baik laki-laki dan perempuan dimotivasi menjadi umat yang senantiasa mengajak kepada kebaikan dan melarang perbuatan yang munkar. Umat dengan kriteria ini, mencerminkan umat yang 
memiliki karakter visioner, progresif, konsisten, empatik, kooperatif dan egaliter. Karakter yang mencerminkan keseimbangan karakter feminin dan maskulin dalam setiap individu manusia.

Menarik untuk mengungkap kata "ummah" yang digunakan dalam ayat ini. Menurut Nasaruddin Umar, pola hidup ummah adalah pola hidup yang mendunia dan lebih menjunjung tinggi prinsip-prinsip keadilan. Berbeda dengan pola hidup kesukuan, promosi karier hanya bergulir di kalangan lakilaki, sedangkan perempuan sulit sekali memperoleh kesempatan itu. Dalam pola hidup ummah, laki-laki dan perempuan terbuka peluang untuk memperoleh kesempatan itu secara adil (Umar, 2001).

Sedangkan redaksi yang mengungkapkan tentang anjuran kepada kebaikan dan mencegah perbuatan yang munkar dalam bentuk umum, memiliki arti universal. Dalam ayat ini tidak diperinci, jenis amar ma'rüf nahi munkar, artinya segala anjuran untuk berbuat baik dan mencegah perbuatan yang mengakibatkan kemunkaran, harus dilakukan secara obyektif dan adil jika ingin menjadi umat yang terbaik (al-Sa'di, 1400 H/1980 M: 87-89).

Jika ajaran agama Islam yang dibawa Nabi Muhammad ini dapat diimplementasikan dengan baik, akan membawa umatnya menjadi umat yang terdepan dan terbaik. Ini dengan catatan, bahwa ajaran Nabi yang agung tersebut harus dilaksanakan dalam rangka kerjasama dan keterpaduan/kesatuan di antara umatnya. Hal ini karena semboyan saling melaksanakan amarma' ruf nahi munkar di antara umat Islam, tidak akan dapat berjalan dan mencapai kesuksesan tanpa kesatuan dan kebersamaan di antara mereka (al-Qushairi, 1420 H/2000 M: juz. I, 165-167). Hal ini sebagaimana dapat ditemukan dalam hadis riwayat Bukhari, no. 149 yang berbunyi:

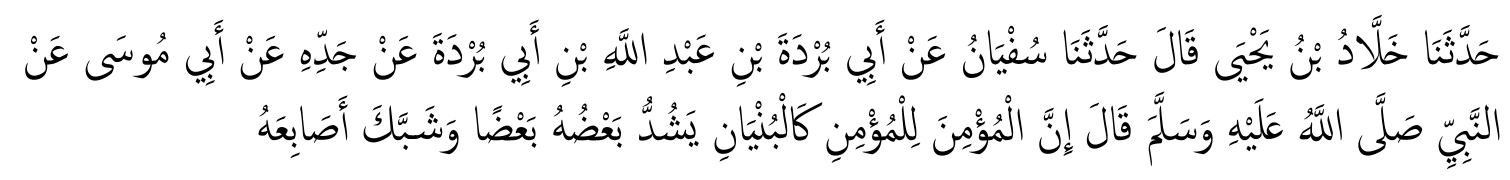

Salah satu contoh perbuatan baik yang diajarkan nabi adalah, menghormati alam dengan berupaya melakukan konservasi lingkungan dan melarang merusak tatanan alami ekosistem alam. Islam memandang perbuatan baik yang dilakukan seorang yang beriman, juga merupakan manifestasi dari bentuk ibadahnya kepada Sang Maha Pencipta. 
Selain itu, Allah juga mengisyaratkan tentang kesetaraan laki-laki dan perempuan dalam berbuat amal yang terbaik demi menunjang kehidupannya di baik di dunia bahkan sampai di akhirat Q.S. al-Nahl [16]: 97:

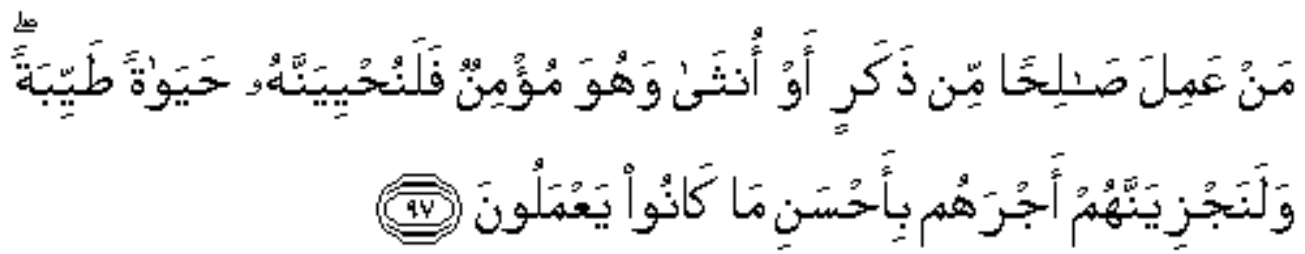

Artinya: Barangsiapa yang mengerjakan amal saleh, baik laki-laki maupun perempuan dalam Keadaan beriman, Maka Sesungguhnya akan Kami berikan kepadanya kehidupan yang baik dan Sesungguhnya akan Kami beri Balasan kepada mereka dengan pahala yang lebih baik dari apa yang telah mereka kerjakan.

Motivasi untuk seorang mukmin baik laki-laki dan perempuan untuk secara kontinu berusaha melakukan usaha terbaik dalam hubungan vertikal dan horizontalnya, sangat ditekankan dalam ayat ini. Hubungan harmonis secara vertikal dengan Allah akan menambah rasa iman dan ketenangan dalam kehidupannya, sedang hubungan secara horizontalnya kepada sesama manusia dan sesama makhluk Allah lainnya, akan menciptakan kehidupan yang damai dan sejahtera bagi manusia dan alam lingkungannya.

Dalam konteks kehidupan sosial ayat di atas mengisyaratkan konsep kesetaraan gender yang ideal dan memberikan ketegasan bahwa prestasi individual, baik dalam bidang spiritual maupun urusan karier profesional, tidak mesti dimonopoli oleh salah satu jenis kelamin saja. Laki-laki dan perempuan memperoleh kesempatan yang sama meraih prestasi optimal. Meskipun kenyataan dalam masyarakat konsep ideal ini masih membutuhkan proses dan sosialisai. (Umar, 2001: 265).

Menurut Muhammad Quraish Shihab, ayat ini merupakan salah satu ayat yang menekankan persamaan antara pria dan wanita. Sebenarnya kata man/siapa pada awal ayat ini sudah dapat menunjuk kepada kedua jenis kelamin -lelaki dan perempuan- tetapi guna penekanan dimaksud, sengaja ayat ini menyebut secara tegas kalimat baik laki-laki maupun perempuan. Ayat ini juga menunjukkan betapa kaum perempuan juga dituntut agar terlibat dalam kegiatan-kegiatan yang bermanfaat, baik untuk diri dan keluarganya, maupun untuk masyarakat dan bangsanya, bahkan kemanusiaan seluruhnya (Shihab, Vol.7, 343).

Selain ayat di atas, Nabi juga bersabda tentang stimulus bagi manusia baik laki-laki dan perempuan untuk mengajak kepada kebaikan, dan melarang mengajak orang pada jalan yang tidak dibenarkan dalam syari'at agama Islam. 
Hal ini sebagaimana sabda nabi dalam sebuah hadis yang diriwayatkan oleh Imam Muslim no. 3831:

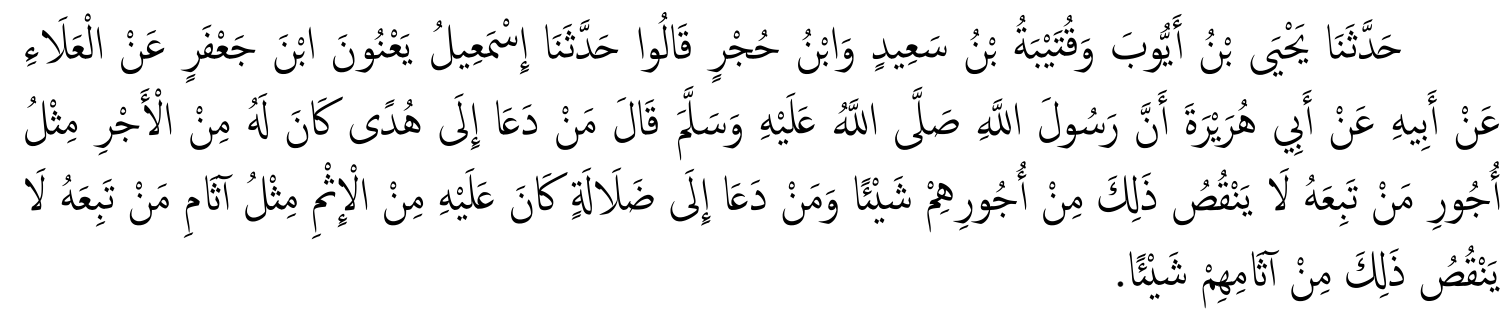

Artinya: menceritakan kepada kami Yahya Ibn Ayyub dan Qutaibah Ibn Sa'íd dan Ibn Hujr, mereka berkata: menceritakan kepada kami Isma'i Ya'nūn Ibn Ja'far dari al-'Ala dari ayahnya dari Abi Hurairah bahwa Rasulullah saw bersabda: barang siapa mengajak kepada kebaikan, maka baginya adalah pahala orang yang mengikutinya tidak dikurangi sedikitpun, dan barang siapa mengajak pada keburukan maka baginya adalah dosa orang yang mengikutinya tidak dikurangi sedikitpun.

Dari beberapa ayat dan hadis di atas dapat dipahami bahwa, Allah dan Rasulnya menegaskan, baik laki-laki dan perempuan yang konsisten dalam melaksanakan ajaran amar ma'rüf nahi munkar dan senantiasa bernaung dalam kesatuan umat Islam yang kokoh, akan mendapatkan balasan dan hasil sesuai dengan apa yang dilakukannya, tanpa dikurangi ganjarannya bahkan hanya untuk perbuatan semisal atompun sebagai partikel yang dianggap terkecil di dunia saat ini.

Dalam karakter muslim yang dapat mengajak amar ma'rüf nahi munkar seperti beberapa ayat dan hadis yang diungkap di atas, dapat diketahui Nabi ingin umatnya memiliki sifat obyektif, komunikatif, aktif, ekspresif, visioner, progresif, independen, empati, egaliter, mau menerima saran, koperatif, dan yang terpenting adalah ikhlas terhadap apa yang dikerjakan.

Ciri khas dari keseimbangan karakter feminin dan maskulin yang positif di atas adalah suatu hal yang niscaya bagi setiap manusia, jika manusia mendambakan memiliki kesempurnaan karakter dalam dirinya. Dari keseimbangan karakter ini, akan menimbulkan keharmonisan interaksi dengan diri sendiri, sesama manusia, alam raya dan dengan Tuhan. Dengan demikian, butuh kerjasama di antara manusia, tanpa harus memandang perbedaan antara laki-laki atau perempuan untuk meraih kesuksesan dalam berbagai bidang termasuk dalam konservasi alam.

Alquran menuntun kaum muslim untuk menegakkan seluruh kemaslahatan mereka, dan jika kemaslahatan tidak dapat dicapai dengan melibatkan semua pihak, maka hendaknya dikerjakan oleh orang yang sanggup 
dan hendaknya orang tersebut meluangkan waktunya agar kemaslahatan dapat tegak dan pandangan mereka menyatu. Kebanyakan kemaslahatan umum universal tidak mungkin dilakukan oleh semua umat Islam, namun sekaligus tidak dapat diabaikan begitu saja. Maka satu-satunya jalan untuk mencapainya adalah dengan melaksanakan petunjuk Allah itu sesuai dengan kemampuan masing-masing individu (lihat: Q.S. Āli ‘Imrān[3]: 104, al-Mā'idah[5]:2, dan al-

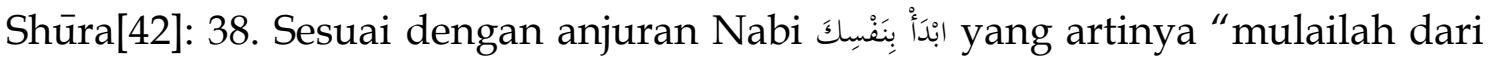
dirimu sendiri (Muslim, juz. III, 78).

Ekoteologi berwawasan gender dalam perspektif Alquran mengajarkan manusia akan pentingnya kesadaran teologis bagi manusia dalam upaya menjalin relasi harmonis dengan dirinya sendiri, kepada sesama manusia, kepada lingkungan, alam raya dan tentu kepada Tuhannya. Relasi harmonis ini adalah sebagai bentuk ibadah dan pertanggungjawaban masing-masing pribadi manusia, laki-laki dan perempuan. Laki-laki dan perempuan memiliki peran dan tugas masing-masing yang disepakati untuk sama-sama meraih prestasi. Untuk kesuksesan bersama, keduanya dapat berkerja secara kooperatif dan komplementer, termasuk dalam upaya konservasi lingkungan.

\section{Simpulan}

Rekonstruksi ekoteologi penting bagi upaya konservasi lingkungan oleh umat manusia baik bagi laki-laki dan perempuan. Dalam teologi Islam, kepercayaan seseorang bahwa alam adalah sebagai bentuk manifestasi cinta Tuhan, akan berimplikasi pada etika orang tersebut dalam menghormati alam. Sikap menghormati alam ini, menjadi awal dari perlakuan dan penggunaan sumber daya alam yang beretika. Alquran memotivasi umat Islam agar selalu berusaha melakukan yang terbaik dalam hidupnya melalui proses yang harus dijalani umat Islam menuju kesuksesan hidup di dunia dan akhirat. Oleh sebab itu, usaha manusia sekecil apapun dalam kebaikan dan keburukan akan mendapat balasan. Manusia akan dapat memperlakukan alam lingkungannya dengan lebih bijak. Manusia tetap dapat menggunakan sumber daya alam baik yang renewable dan non renewable, tetapi dengan grand planning yang dapat dipertanggungjawabkan baik kepada Tuhan maupun kepada sesama manusia. Kebijakan manusia inilah yang pada gilirannya, akan dapat menciptakan kehidupan yang bahagia dan ketentraman bagi manusia dan alam itu sendiri. Tidak cukup menyelesaikan masalah kerusakan hanya dengan mengandalkan teknologi, tapi harus dimulai dari pola pikir dan aksi yang terintegrasi antara ajaran agama dan sains. 
Stereotipe tentang karakter yang diidentikan bagi laki-laki dan perempuan yang menjadi akar permasalahan relasi gender yang inharmonis ternyata tidak ditemukan dalam Alquran. Dengan demikian, aplikasi ekoteologi berwawasan gender di atas bagi laki-laki dan perempuan, menjadi ujung tombak keberhasilan konsep ideal dan ajaran universal Alquran tentang konservasi lingkungan. Keduanya memiliki kesempatan yang sama untuk sukses sebagai wakil Allah, yaitu sebagai "pelindung dan pemakmur" bumi. 


\section{DAFTAR PUSTAKA}

Al-Qurān al-Karim

Amrullah, Abdul Malik Abdul Karim., 2000, Tafsir al-Azhar, Jakarta: Pustaka Panji Mas.

Arne Naess, 1995,The Deep Ecology Movement; Some Philosophical Aspect dalam Session G. (ed). Deep Ecology for 21th Century, Boston: t.p.

Bina, Agarwal., 1992, “The Gender and Environment Debate: Lesson from India”, Feminist Studies. College Park: Spring, Vol. 18, Iss. I.

al-Biqāi i, Burhān al-Dỉn Abỉ al-Ḥasan Ibrāhỉm Ibn 'Amr., 1415 H/1995 M, Naẓm al-Durar fi Tanāsub al-Ayât wa al-Suwar, Beirut: Dār al-Kutub al-'Ilmiyyah, cet. I.

Bolen, Jean Shinoda., 2004, Crossing to Avalon, A Woman's Midlife Quest for the Sacred Feminine, San Fransisco: Harper Collins, cet. X.

Canas, Mercedes., 1996, In Us Life Grows an Ecofeminist Point of View, dalam: Woman Healing Earth Third Women on Ecology, Feminism and Religion, edited by: Rosemary Radford Ruether, USA: SCM Press Ltd, cet. I.

Cuamo, Chris J., 1998, Feminism and Ecological Communities an Ethic of Flourishing, New York: Rotledge.

Daly, Mary., 1978, Gyn/Ecology: The Metaethics of Radical Feminism, Boston: Beacon Press.

al-Din, Muhammad al-Rạzỉ Fakhr., 1415 H/1995 M, Tafsỉ al-Kabir wa Mafātiḥ al-Ghaib, Beirūt: Dār al-Fikr.

al-Farmawi, 'Abd al-Hayy, al-Bidāyah fi al-Tafsì al-Maudūi : Dirāsah Manhajiyah Maudu'iyyah, Mesir: Maktabah al-Jumhūriyyah, t.th.

Febriani, Nur Arfiyah., 2014, Ekologi Berwawasan Gender dalam Perspektifal-Quran, Bandung: Mizan.

Gore, Albert Jr., 1992, Earth in Balance: Ecology and Human Spirit, New York: Houghton Mifflin.

Greenway, William., "A New Climate for Theology: God, The World, and Global Warming/Ecologies of Grace: Environmenal Ethics and Christian Ecology," Interpretation, (Richmond: January 2010): Vol. 64.

Griffin, Susan., 1978,Woman and Nature: The Roaring within Her, New York: Harper and Row.

Harold W. Wood, Jr., "Modern Pantheism as an Approach to Environmental Ethics", Journal Environmenatal Ethics, Summer 1985, 51. 
Inisiasi Ekoteologi Berwawasan Gender ...

Harun Nasution., 1986, Teologi Islam: Analisa Sejarah dan Perbandingan, Jakarta: UI Press, cet. IV.

Hawwā, Sa id., 1989, al-Asās fi al-Tafsìr, Kairo: Dār al-Salām, cet. II.

Hessing, Melody., "Woman and Sustainbility: Ecofeminist Perspectives" dalam Alternatives, Waterloo: Aug 1993. Vol. 19, Iss. 4; 3.

Ibn Kathỉ, Abỉ al-Fidā' al-Ismā'il Ibn 'Umar al-Dimashqi., 1420 H/1999 M, Tafsir al-Qurān al-'Azìm, Beirūt: Dār al-Kutub Ilmiyyah.

Jaoudi, Maria., 1993, Christian and Islamic Spirituality Sharing a Journey, New York: Paulist Press.

Jauhari, Ṭanțawi., t.th, al-Jawahir fi Tafsir al-Qur'ān al-Karim, Beirut: Dār al-Fikr.

JB. Banawiratma Sj dan J Muller., 1993 Berteologi Sosial Lintas Ilmu, Yogyakarta: Kanisius, cet. I.

Kartanegara, Mulyadi., 2006, Reaktualisasi Tradisi Ilmiah Islam, Jakarta: Baitul Ihsan.

Merchant,Carolyn., 1980, The Death of Nature: Women, Ecology, and the Scientific Revolution, San Fransisco: Harper and Row.

Mudofir., 2009 "Argumen Konservasi Lingkungan sebagai Tujuan Tertinggi Syari'ah," Disertasi di Universitas Islam Negeri (UIN) Syarif Hidayatullah Jakarta.

Mujiono., 2001 “Teologi Lingkungan”, Disertasi di Universitas Islam Negeri (UIN) Syarif Hidayatullah Jakarta."

al-Majlisì, Shaikh Muhammad Bāqir., 1983 M/1403 H, Bihär al-Anwār al-Jāmi'ah li Durar Akhbār al-A'immah al-Ațhār, Beirūt: Dār Ihỵā' al-Turāth al-'Arabi,.

al-Nasaiburi, Abu al-Husain Muslim Ibn al-Hajjāj Ibn Muslim al-Qushairi., t.th, al-Jāmi'al-Șaḥiḥ al-Musammā Șaḥiḥ Muslim, Beirut: Dār al-Afāq al-Jadidah.

al-Nursi, Badi' al-Zamān Sa'id., 1999 H/1420 M, al-Mathnawi al-'Arabi al-Nüri, yang ditaḥ̣ị oleh Ihsān Qāsim al-Ṣāliḥ̣i, Istanbūl: Dār Sozler, cet. IV.

Nasr, Hossein., 2004, Intelegensi E Spiritualitas Agama-agama, terj. Suharsono dkk., Jogjakarta: Inisiasi Press.

Noer, Kautsar Azhari., 1999, "Menyemarakkan Dialog Agama", dalam Dekonstruksi Mazhab Ciputat, Bandung: Aman Wacana Mulia.

., 2002, Tasawuf Perenial Kearifan Kritis Kaum Sufi, Jakarta: PT. SERAMBI ILMU SEMESTA, cet. I.

Plewes, Betty dan Ricky Stuart., 1991, Women and Development Revisited: The Case for a Gender and Development Approachm, Toronto: Between the Lines. 
al-Qarḍ̄wīi, Yūsuf., 2001, Ri'âyah al-Bỉah fi Sharīah al-Islām, Kairo: Dạr alShurūq.

al-Qațāan, Manna' Khalil., 1973, Mabahith fi ‘Ulum al-Qur'ān, t.tp: Manshurat al'Așr al-Hadith, cet. III.

al-Qushairi, Abì al-Qāsim 'Abd al-Karim Ibn Hawāzin Ibn Abi Mālik' alNaisāburì al-Shāfíi., 1420 H/2000 M, Tafsir al-Qushairi al-Musammä Lațā if al-Ishārāt, Beirut: Dār al-Kutub al-'Ilmiyyah.

Rahman, Fazlur, 1999, Major Themes of the Qur'an, Kuala Lumpur: Islamic Book Trust.

al-Sa'di, Shaikh 'Abd al-Raḥmān Nașir., 1400 H/1980 M, al-Qawa’id al-Hisā̄n li Tafsìr al-Qur'ān, Riyād: Maktabah al-Ma'ārif.

al-Syaukani, A. Luthfi., 1998, “Tipologi dan Wacana Pemikiran Arab Kontemporer, Jurnal Paramadina", vol.I, no. 1, Juli-Desember.

Shihab, Muhammad Quraish., 2005, Tafsir al-Mishbah Pesan Kesan Keserasian alQuran, Jakarta: Lentera Hati.

Shiva,Vandana., 1996, "Let Us Survive, Women, Ecology and Development," dalam Rosemary Radford Ruether, Women Healing Earth, Third World Women on Ecology, Feminism, and Religion, London: SCM Press Ltd, cet. I.

-------., 1988, Staying Alive: Women, Ecology and Survival,London: Zed Books, 1988.

Starhawk., 1987, Truth or Dare, New York: Harper and Row.

Suwito NS., 2011, “Eko-Sufisme Studi tentang Usaha Pelestarian Lingkungan pada Jama'ah Mujahadah Ilmu Giri dan Jama'ah Aoliya' Jogjakarta", Jogjakarta: Buku Litera.

Umar, Nasaruddin., 2001, Argumen Kesetaraan Gender Perspektifal-Qur'an, Jakarta: Paramadina.

Vance, Linda., 1997, "Ecofeminism and Wilderness", NWSA Journal. Bloomington: Fall, Vol. 9, Issue. 3; 1.

Warren, Karen J., 1994, Ecological Feminism, New York: Routledge.

Wollstonecraft, Mary., 1995, Women's Realities, Womens Choice, New York: Oxford University Press. 
Halaman ini tidak sengaja untuk dikosongkan 